\title{
Insulin VNTR and IGF-1 Promoter Region Polymorphisms Are Not Associated with Body Composition in Early Childhood: The Generation R Study
}

\author{
Janneke A.J.B.M. Maas ${ }^{a}$ bennis O. Mook-Kanamori ${ }^{a-c}$ Lamise Ay ${ }^{a-c}$ \\ Eric A.P. Steegers ${ }^{d}$ Cornelia M. van Duijn ${ }^{b}$ Albert Hofman ${ }^{b}$ \\ Anita C.S. Hokken-Koelega ${ }^{c}$ Vincent W.V. Jaddoe ${ }^{a-c}$ \\ ${ }^{a}$ The Generation R Study Group and Departments of ${ }^{b}$ Epidemiology, ${ }^{c}$ Pediatrics, and \\ dObstetrics and Gynaecology, Erasmus Medical Center, Rotterdam, The Netherlands
}

\section{Key Words \\ Cohort studies · Genetics • Infancy • Insulin • Obesity}

\begin{abstract}
Objective: The objective of this study was to examine the associations between insulin gene variable number of tandem repeats (INS VNTR) and insulin-like growth factor 1 (IGF1) gene promoter region polymorphisms with body composition in early childhood. Methods: This study was embedded in an ongoing prospective cohort study. Growth in early childhood (body mass index, total subcutaneous fat mass and waist-hip ratio) was assessed at birth and at the ages of 6 weeks and 24 months. DNA for genotyping was available in 738 children. Results: The genotype distribution of the INS VNTR gene was I/I 50.4\%, I/III 40.4\%, and III/III 9.2\%. IGF1 genotypes were categorized in the following categories based on their 192-bp allele: homozygous (wild-type) 43.1\%, heterozygous $45.8 \%$, and noncarrier $11.2 \%$. No differences were found in body mass index, total subcutaneous fat mass and waist-hip ratio in early childhood between the three groups for both the INS VNTR and IGF1 genotypes. We also did not find interactions between these genotypes and gen-
\end{abstract}

\section{KARGER}

Fax +4161306 1234

E-Mail karger@karger.ch

www.karger.com
C) 2010 S. Karger AG, Basel

$1663-2818 / 10 / 0732-0120 \$ 26.00 / 0$

Accessible online at:

www.karger.com/hrp der or birth weight on the effects of body composition measures. Conclusions: Our results do not support previous studies showing associations between INS VNTR and IGFI promoter region polymorphisms with body composition in early childhood.

Copyright $\odot 2010$ S. Karger AG, Basel

\section{Introduction}

Common polymorphisms of the insulin gene variable number of tandem repeats (INS VNTR) and the insulinlike growth factor 1 (IGF1) are associated with variations in early growth and body composition [1]. INS VNTR is known to have functional effects on circulating insulin levels, which may influence fetal and early postnatal growth [2]. Several studies have suggested that this polymorphism is associated with size at birth, childhood and adult obesity, type 2 diabetes and insulin resistance [3-5]. However, thus far, findings seem to be rather inconsistent $[1,4,6]$. We have previously found an association of INS VNTR with a gestational duration but not with birth weight [4]. A common promoter region polymorphism of 
the IGF1 gene, which is associated with circulating IGF-1 levels, has been suggested to affect birth weight, adult height and the risk of type 2 diabetes [1, 7-11]. We and others could not replicate an association between variants of the IGF1 promoter region and birth weight $[1,12$, 13]. Also, we could not replicate previously suggested associations of this polymorphism with weight gain during infancy [1].

Both polymorphisms have also been suggested to be associated with various measures of body composition, such as body mass index (BMI), fat mass and waist circumference $[1,3,5,11,14,15]$. To our knowledge, no studies have examined the associations of these common polymorphisms with body composition in infancy and early childhood. It is known that measures of body composition track from early childhood onwards [16-18]. The genetic component of variations in body composition may be larger in early life when the effects of lifestyle habits may be limited.

Therefore, in addition to our previous reports focused on associations between INS VNTR and IGF1 gene polymorphisms with weight and height in fetal life and early infancy $[4,13]$, this study examined in the same prenatally recruited prospective cohort study, the associations of INS VNTR and IGF1 gene polymorphism with different measures of body composition at the ages of 6 weeks and 24 months.

\section{Subjects and Methods}

Design

This study was embedded in the Generation R Study, a prospective cohort study from fetal life until young adulthood in Rotterdam, The Netherlands. This study is designed to identify early environmental and genetic determinants of growth, development and health from early fetal life onwards $[19,20]$. In total, the cohort includes 9,778 mothers and their children. Additional, more detailed assessments of fetal and postnatal growth and development were conducted in a subgroup of 1,232 parents and their children, referred to as the Generation R Focus cohort. This subgroup is homogeneously ethnic to exclude possible confounding or effect modification by ethnicity. Of all approached women, $80 \%$ were enrolled in this subgroup study in late pregnancy (gestational age of 30 weeks). In this subgroup, postnatal examinations were performed at the ages of 6 weeks and 24 months. The study has been approved by the Medical Ethics Committee of the Erasmus Medical Center, Rotterdam. Written informed consent was obtained from all participants or their parents.

Population for Analysis

In total, 1,232 women were enrolled in the Generation R Focus Study. Pregnancies leading to perinatal death $(n=2)$ were excluded from the present analysis. DNA was collected from cord blood and available for 884 subjects. In total, 744 children were included in this study, of whom genotyping for INS VNTR and IGF1 gene was successful in 738 and 627 children, respectively. Missing cord blood samples were mainly due to logistical and clinical constraints during delivery. Response rates for DNA samples were lower among complicated pregnancies and deliveries.

\section{Genotyping Assays INS VNTR and IGF1 Gene}

DNA was collected from cord blood samples of the children at birth. For INS VNTR polymerase chain reaction was performed to amplify the $-23 / H p h I$ single nucleotide polymorphism (A/T), which is known to be in almost complete linkage disequilibrium with INS VNTR class [21]. The INS VNTR genotypes were categorized in three classes: I/I, I/III and III/III. INS VNTR is imprinted with the paternally inherited allele being expressed [22]. The I/III heterozygote group can be considered as an indeterminate group, consisting partly of individuals in whom the I allele is expressed and partly of individuals in whom the III allele is expressed. Therefore, although the I/III and III/III genotype groups were both separately compared with the I/I group (reference group), the main interest in our analyses was on the difference between the I/I and the III/III heterozygous subjects.

As for $I G F 1$, polymerase chain reaction was performed using oligonucleotide primers designed to amplify the polymorphic cytosine-adenine repeat $1 \mathrm{~kb}$ upstream of the human IGF1 gene as previously described $[13,23]$. As in former studies, IGF1 genotypes were categorized in the following categories based on their 192-bp allele: homozygous (wild-type), heterozygous and noncarrier $[1,10,12,13,24]$. In both polymorphisms, the genotype distribution was similar to those found in previous studies and the frequency distribution did not deviate from the Hardy-Weinberg equilibrium $[1,3,9,25]$.

\section{Body Composition}

At the ages of 6 weeks and 24 months, all subjects were invited to the research center. Four well-trained medical assistants took all measurements. Anthropometrics were measured without clothes.

Weight was measured to the nearest gram using an electronic scale $\left(\right.$ Seca $\left.^{\circledR}\right)$ at 6 weeks of age and a mechanical scale $\left(\operatorname{Seca}^{\circledR}\right)$ at 24 months of age. Height was measured to the nearest millimeter in supine position using a neonanometer (Holtain Limited ${ }^{\circledR}$ ) at the age of 6 weeks and in standing position by a Harpender stadiometer (Holtain Limited ${ }^{\circledR}$ ) at the age of 24 months. BMI was calculated as weight $/$ height ${ }^{2}\left(\mathrm{~kg} / \mathrm{m}^{2}\right)$. At 6 weeks, we calculated ponderal index (weight $/$ height $^{3}\left(\mathrm{~kg} / \mathrm{m}^{3}\right)$ ), because this measurement is known to be a better indicator for body composition in newborns than BMI [26].

Subcutaneous fat mass ( $\mathrm{mm}$ ) was measured by skin fold thicknesses (SFTs), which are valid measurements for use in epidemiological studies $[27,28]$. SFTs were measured under standard conditions by using a standard skin fold caliper (SlimGuide; Creative Health Products ${ }^{\circledR}$ ). Measurements were taken, as previously described, on the left side of the body at four different sites: triceps, biceps, subscapular and suprailiacal [27]. The consensus between and among observers for the medical assistants was analyzed using the intraclass correlation coefficient (ICC). Intraobserver ICC was 0.88 and interobserver ICC was $0.76[29,30]$. The skin fold caliper was operated with a constant pressure of $10 \mathrm{~g} / \mathrm{mm}^{3}$. Total subcutaneous fat mass (TSFM) (mm) was calculated from the 
Table 1. Maternal and child characteristics and genotype frequency distribution

\begin{tabular}{lc}
\hline Maternal characteristics & $\mathrm{n}=744$ \\
Age, years & $32.1(31.5-32.1)$ \\
Weight before pregnancy, kg & $69.0(12.7)$ \\
Height, cm & $171.0(6.4)$ \\
BMI & $23.5(4.1)$ \\
Parity, nulliparous & $59.7 \%$ \\
Smoking & $70.4 \%$ \\
$\quad$ No & $9.0 \%$ \\
Yes, until pregnancy & $11.8 \%$ \\
Yes, throughout pregnancy & $\mathrm{n}=744$ \\
\hline Birth characteristics & $40.3(39.9-40.2)$ \\
Gestational age, weeks & $3,516(523)$ \\
Weight, g & $51.9 \%$ \\
Gender, boys & $\mathrm{n}=657$ \\
\hline Postnatal characteristics 6 weeks & $6.3(6.6-6.9)$ \\
Age at visit, weeks & $4,892(697)$ \\
Weight, g & $56.8(2.6)$ \\
Height, cm & $15.1(1.4)$ \\
BMI & $23.6(7.0)$ \\
TSFM, mm & $26.7(2.5)$ \\
Ponderal index, kg/m ${ }^{3}$ & $\mathrm{n}=629$ \\
\hline Postnatal characteristics 24 months & $25.1(25.3-25.4)$ \\
Age at visit, months & $12,672(1,405)$ \\
Weight, g & $89.1(3.2)$ \\
Height, cm & $16.0(1.3)$ \\
BMI & $27.1(6.6)$ \\
TSFM, mm & $0.99(0.05)$ \\
WHR & $\mathrm{n}=738$ \\
\hline INS VNTR class genotype & $50.4 \%$ \\
I/I & $40.4 \%$ \\
I/III & $9.2 \%$ \\
III/III & \\
\hline IGF1 genotype & \\
Homozygous & \\
Neterozygous & \\
Noncarrier & \\
\hline
\end{tabular}

Values are means (SDS), medians (95\% range) for variables with skewed distribution or percentages. Of the total group, data were missing on maternal weight and BMI before pregnancy ( $\mathrm{n}=$ $127)$, parity $(n=1)$ and smoking habits $(n=65)$. The allele distribution is based on 2 alleles per infant.

sum of triceps SFT + biceps SFT + subscapular SFT + suprailiacal SFT [29].

Waist circumference was measured at the minimum circumference between the iliac crest and the rib cage and hip circumference was measured at the maximum width over the greater trochanters using a flexible steel tape to the nearest millimeter. Waist-hip ratio (WHR) was then calculated as waist circumference divided by hip circumference.

\section{Covariates}

Information on maternal age, parity and weight before pregnancy was obtained by a questionnaire at the enrolment in the study. Maternal smoking habits were assessed in each questionnaire. Maternal height was measured without shoes at our research center. BMI (weight before pregnancy/height ${ }^{2}$ ) was calculated. Birth weight, date of birth and gender were obtained from community midwife and hospital registries.

\section{Data Analysis}

Power calculation was based on previous studies showing associations of INS VNTR and IGF1 with measures of body composition $[1,3,5,9,14,15]$. With a genotype frequency of $10 \%$, a difference of 0.3 standard deviation can be detected (type I error $5 \%$, type II error $20 \%$, and power $80 \%$ ). This difference is much smaller than shown in previous studies. Multiple linear regression models were performed to assess the associations of the INS VNTR with BMI, TSFM and WHR at the ages of 6 weeks and 24 months cross-sectionally. These models were adjusted for gender and current age. To take account for differences between observers, we have also adjusted the analyses for the specific observer as covariate. Age, weight, height, BMI and smoking habits of the mother and parity did not change the effect estimates and were therefore not included in the final analyses. Subsequently, we tested the interaction of INS VNTR with gender and birth weight. Similar analyses as for INS VNTR were performed for the IGFI gene. Additionally, we used a different stratification of genotype groups; presence and absence of 192/194 bp. Recent studies have shown that subjects who were homozygous for the 192-bp or the 194-bp allele had comparable IGF-1 blood levels, while individuals who were homozygous for either alleles shorter than $192 \mathrm{bp}$ or longer than 194 bp had significantly lower serum IGF-1 levels [11, $31,32]$. Therefore, we assumed that all subjects who were homozygous for 192 or 194 bp or were carriers of both the 192-bp allele and the 194-bp allele could be regarded as the wild-type group. Consequently, all subjects who were carriers of at least one variant allele (either less than 192 bp or more than 194 bp) were grouped as variant carriers. All measures of association are presented with their 95\% confidence intervals (CI). All statistical analyses were performed using the Statistical Package of Social Sciences version 11.0 for Windows (SPSS, Inc., Chicago, Ill., USA).

\section{Results}

A total of 744 subjects were included in the study. Maternal and child characteristics are shown in table 1 , as well is the genotype frequency distribution. The DNA for genotyping of INS VNTR was available in 738 subjects. The IGF1 promoter region was determined in 627 subjects. Gender distribution was similar in the genotype groups for both genes. At 6 weeks, 657 subjects participated in the postnatal assessment, at 2 years this number was 629.

The INS VNTR genotype distribution in this study was $50.4,40.4$ and $9.2 \%$ for class I/I, I/III and III/III, re- 
Fig. 1. INS VNTR gene promoter region polymorphism and body composition in early childhood. a-c Mean differences (and the 95\% CI) in body composition according to INS VNTR genotype at 6 weeks and 24 months of age based on multiple linear regression models. The I/I group is used as reference group and the models are adjusted for gender and age.

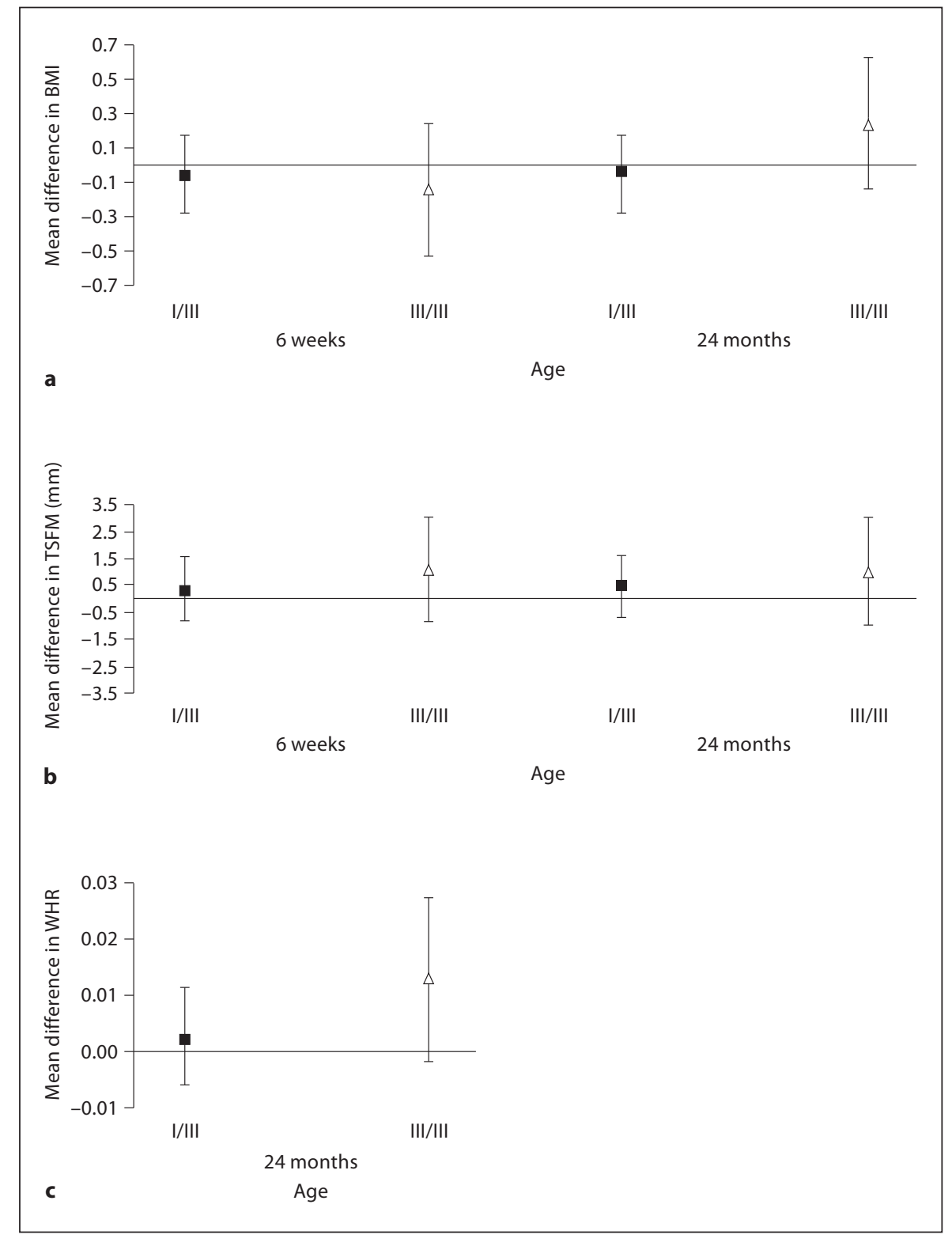

spectively (table 1). Differences in BMI, TSFM and WHR between the genotype groups at each age are given in figure 1. These estimated differences were based on multiple linear regression models and genotype group I/I was used as reference. No statistically significant associations ( $p>$ 0.05 ) were found with the different measurements of body composition at 6 weeks and 24 months.

Subsequently we looked at the interaction of INS VNTR with gender and birth weight at 6 weeks. We did not find a significant association between these determinants. In table 2 the association of INS VNTR with BMI, TSFM and WHR at 24 months stratified by gender is pre- sented. No significant differences in any measure of body composition between the different genotypes were present in boys or girls.

For the IGF1 gene, $43.1 \%$ subjects were 192 bp homozygous, $45.8 \%$ were 192 bp heterozygous, and $11.2 \%$ subjects were noncarriers. Again no significant differences were observed in the maternal, birth and postnatal characteristics between these three groups. Figure 2 represents the differences in BMI, TSFM and WHR at 6 weeks and 24 months between the IGF1 genotype groups. No differences in body composition were found at any age and no significant association was found in the interac- 
Table 2. Associations of INS VNTR genotypes with body composition at 24 months by gender

\begin{tabular}{lll}
\hline $\begin{array}{l}\text { INS VNTR } \\
\text { class genotype }\end{array}$ & Boys & Girls \\
\hline $\begin{array}{l}\text { Difference in BMI } \\
\text { I/I }\end{array}$ & \\
I/III & reference & reference \\
III/III & $-0.13(-0.45,0.19)$ & $0.04(-0.28,0.36)$ \\
\hline Difference in TSFM, mm & $0.30(-0.22,0.83)$ & $0.13(-0.44,0.71)$ \\
I/I & reference & reference \\
I/III & $-0.15(-1.85,1.55)$ & $1.12(-0.53,2.77)$ \\
III/III & $1.22(-1.59,4.03)$ & $0.61(-2.28,3.50)$ \\
\hline Difference in WHR & & \\
I/I & reference & reference \\
I/III & $0.01(-0.01,0.02)$ & $0.00(-0.01,0,01)$ \\
III/III & $0.01(-0.01,0.03)$ & $0.02(-0.01,0.04)$ \\
\hline
\end{tabular}

Values are regression coefficients (95\% CI) and reflect the difference in body composition. Differences are adjusted for current age. Analyses are based on the following numbers: boys: $\mathrm{I} / \mathrm{I}, \mathrm{n}=$ 129 (45\%), I/III, $\mathrm{n}=131$ (45\%) and III/III, $\mathrm{n}=30$ (10\%); girls: I/I, $\mathrm{n}=154(55 \%), \mathrm{I} / \mathrm{III}, \mathrm{n}=105(37 \%)$ and III/III, $\mathrm{n}=22(8 \%)$.

tion of IGF1 genotype with gender and birth weight at 6 weeks. The association between IGF1 genotype and body composition at 24 months by gender is shown in table 3 . No differences in body composition were found.

Classification of the IGF1 gene promoter polymorphism based on the presence and absence of the 192-/194bp allele genotypes showed that this genotype was present in $442(70.5 \%)$ and absent in $182(29.5 \%)$ subjects. Again no differences were found in body composition in early childhood between the two groups (data not shown).

There were no differences found in ponderal index at 6 weeks in the variant carriers of INS VNTR (differences: $\left.-0.05(95 \% \mathrm{CI}-0.76,0.67) \mathrm{kg} / \mathrm{m}^{3}\right)$ and IGF1 genotypes (differences: $\left.-0.19(95 \% \mathrm{CI}-0.92,0.54) \mathrm{kg} / \mathrm{m}^{3}\right)$.

\section{Discussion}

In this population-based prospective cohort study, the associations between a polymorphism in INS VNTR and in the promoter region of the IGF1 gene and parameters of body composition were investigated. Body composition was measured by BMI, TSFM and WHR. No differences were found in these polymorphisms in relation to body composition.
Table 3. Associations of IGF1 genotypes with body composition at 24 months by gender

\begin{tabular}{lll}
\hline IGF1 genotype & Boys & Girls \\
\hline Difference in BMI & & \\
Homozygous & reference & reference \\
Heterozygous & $-0.05(-0.41,0.32)$ & $-0.23(-0.57,0.12)$ \\
Noncarrier & $0.05(-0.48,0.58)$ & $-0.39(-0.98,0.20)$ \\
\hline Difference in TSFM, mm & reference & reference \\
Homozygous & $0.04(-1.88,1.97)$ & $-1.15(-2.84,0.54)$ \\
Heterozygous & $-0.46(-3.10,2.19)$ & $-2.04(-5.07,0.99)$ \\
Noncarrier & & \\
\hline Difference in WHR & reference & reference \\
Homozygous & $0.01(0.00,0.02)$ & $0.00(-0.01,0,02)$ \\
Heterozygous & $0.01(-0.01,0.03)$ & $0.00(-0.03,0.02)$ \\
Noncarrier &
\end{tabular}

Values are regression coefficients $(95 \% \mathrm{CI})$ and reflect the difference in body composition. Differences are adjusted for current age. Analyses are based on the following numbers: boys: homozygous, $\mathrm{n}=107$ (43\%), heterozygous, $\mathrm{n}=108$ (44\%) and noncarrier, $\mathrm{n}=33$ (13\%); girls: homozygous, $\mathrm{n}=97$ (40\%), heterozygous, $\mathrm{n}=$ $120(50 \%)$ and noncarrier, $\mathrm{n}=23(10 \%)$.

To our knowledge, this study is the first prospective cohort that examined the association between polymorphisms in the INS VNTR and IGF1 gene and body composition in early childhood. DNA was collected from cord blood and available for 884 subjects. In total, 744 children were included in this study, of whom genotyping for INS VNTR and IGF1 gene was successful in 738 and 627 subjects, respectively. Missing cord blood and DNA samples were mainly due to logistical and clinical constraints during delivery. Response rates for DNA samples were lower among complicated pregnancies and deliveries. As a consequence, children who were not genotyped had a shorter gestational age at birth (difference: -0.49 $(95 \%$ CI $-0.73,-0.25)$ weeks, $\mathrm{p}<0.01)$ and a lower birth weight (difference: -108.0 (95\% CI -182.1, -0.34.0) grams, $\mathrm{p}<0.01)$. The numbers of children with low birth weight $(\mathrm{n}=12)$ or preterm birth $(\mathrm{n}=25)$ were lower than expected. Lack of variation in birth weight could lead to an underestimation of the effect. However, previous studies did not consistently show associations between these two genetic variants and birth weight. Measurements of body composition were available in $657(88 \%)$ subjects at 6 weeks and in $629(85 \%)$ subjects at 24 months. Our effect estimates would be biased or underestimated if the associations between INS VNTR and IGF1 genotype and 
Fig. 2. IGF1 gene promoter region polymorphism and body composition in early childhood. a-c Mean differences (and the $95 \% \mathrm{CI}$ ) in body composition according to IGF1 genotype at 6 weeks and 24 months of age based on multiple linear regression models. The homozygous group is used as reference group and the models are adjusted for gender and age. $\mathrm{HZ}=$ Heterozygous, $\mathrm{NC}=$ noncarrier.

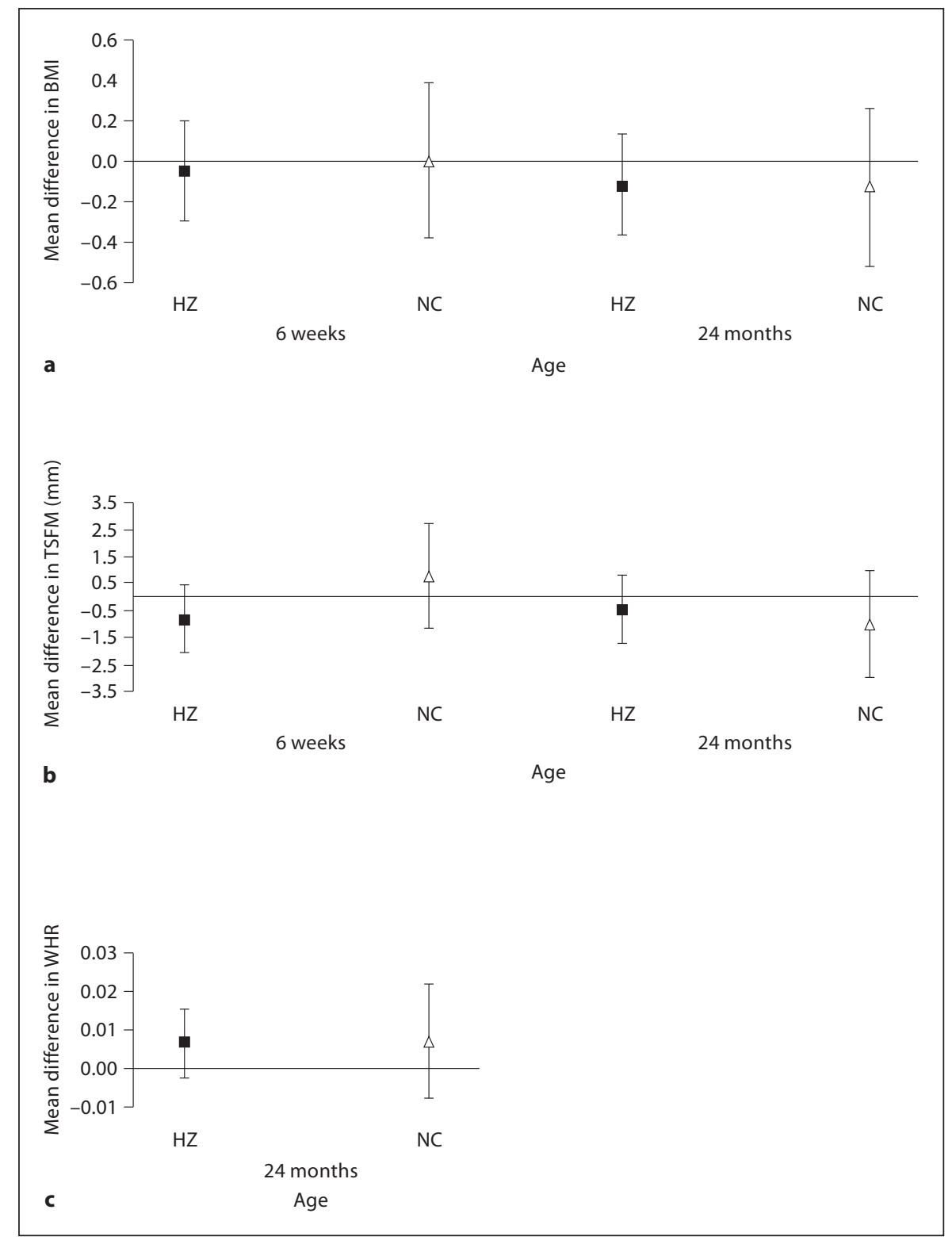

growth characteristics differ between those with and without complete data. This seems unlikely but cannot be excluded. However, generalization of our results to children born preterm or with low birth weight is limited.

Previous studies have shown a relationship between the INS VNTR genotype and body composition. The class III genotype was associated with larger BMI, body weight, fat mass and waist circumference $[3,5,14,15]$. These studies concluded that subjects homozygous for the INS VNTR class III allele may have a larger tendency to gain weight through the accumulation of fat, which is closely associated with insulin resistance [15]. Our data however did not show an association between the INS VNTR genotype and different parameters of body composition in early childhood. Our findings are in line with a large German [1] and Finnish [6] study, which also failed to confirm an association between a polymorphism in INS VNTR and body composition. These inconsistent findings are not likely to be explained by ethnic differences in VNTR subclass composition, presence (or absence) of nearby modifying variants, or variable local linkage disequilibrium relationships because these are known to be broadly similar in all non-African populations [21]. Another explanation could be that biological differences between the 
various study samples (e.g., environmental exposures, antenatal management, secular trends) and/or to study design-related issues (accuracy and choice of measurements of body composition) have an effect on the power to detect VNTR association effects.

In the present study, we did not find an association between INS VNTR and IGF1 gene polymorphisms and different parameters of body composition. These findings are in line with our previous reports, in which we described no association between INS VNTR and IGF1 gene polymorphisms with weight and height at various ages from fetal life until infancy $[4,13]$. Landmann et al. [1] found that the absence of the common 192-bp allele of the IGF1 gene is associated with an accelerated weight gain in the first year of life. Vaessen et al. [9] found that the absence of the 192-bp allele was associated with a decreased adult height. In the same cohort, noncarriers had a lower birth weight [10]. These differences could be explained by differences in study design. One of the major strengths of our study is that we examined the association of the IGF1 gene promoter polymorphism with different parameters of body composition rather than, as previously performed, with only birth or postnatal weight. Measurements of body composition give a more complete picture of the distribution of fat mass, because they provide regional data instead of whole body data. Health risks associated with overweight are now known to derive primarily from fat rather than weight [33]. Body composition is therefore a better risk indicator for developing overweight of obesity [34, 35].

Recently, Voorhoeve et al. [11] examined the association between the IGF1 gene polymorphism and body fatness. They found that body weight, BMI, fat mass, waist circumference and hip circumference were higher in female variant carriers of the IGF1 polymorphism. A similar trend was seen in boys. We could not replicate these findings, even after using the same stratification. This could be explained by the difference in age of the subjects. The subjects in the study of Voorhoeve were between 10.7 and 13.6 years as we examined subjects until the age of 2 years. Furthermore, the subjects of Voorhoeve were born between 1981 and 1989, while our subjects were born between 2003 and 2005. In line with Voorhoeve, we expected that our younger cohort would show a stronger relationship between the IGF1 genotype and body composition, because it is known from recent epidemiological studies that the prevalence of overweight and obesity is increasing worldwide. The discrepancy between our results and the results of Voorhoeve could mean that it takes some time to develop the differences in body com- position based on $I G F 1$ genotype. At the age of 2 years, the differences between genotypes are not yet present. It is also possible that the differences between genotypes found by Voorhoeve are significant by chance because they were very small. Thus far, our and previous studies show rather inconsistent associations with growth characteristics in early life. Chance findings cannot therefore be excluded. Further studies in larger cohorts are necessary to study the effect of this IGF1 promoter polymorphism with growth from fetal to early postnatal life.

In conclusion, this study demonstrates that a polymorphism in the INS VNTR and IGFI gene is not associated with body composition in early childhood. Longer follow-up studies are needed to examine whether and at which age differences develop in body composition between polymorphisms in the INS VTNR and IGF1 genotype. Currently, studies are being performed for further follow-up measurements in our cohort. Also systematic searches for disease-associated common variants by means of genome-wide association studies may enable us to purchase a more complete understanding of the entire IGF1 and VNTR-INS-IGF2 region and its relationship to growth and morbidity in childhood and later life.

\section{Acknowledgements}

The Generation R Study is conducted by the Erasmus Medical Center in close collaboration with the School of Law and Faculty of Social Sciences of the Erasmus University Rotterdam, the Municipal Health Service Rotterdam area, Rotterdam, the Rotterdam Homecare Foundation, Rotterdam and the Stichting Trombosedienst \& Artsenlaboratorium Rijnmond (STAR), Rotterdam. We gratefully acknowledge the contribution of general practitioners, hospitals, midwives and pharmacies in Rotterdam. The first phase of the Generation R Study is made possible by financial support from the Erasmus Medical Center, Rotterdam, the Erasmus University Rotterdam and The Netherlands Organization for Health Research and Development (ZonMw). The study described in this paper was made possible by an additional grant from the National Diabetic Fund (Grant No. 2002.00.035).

References

1 Landmann E, Geller F, Schilling J, Rudloff S, Foeller-Gaudier E, Gortner L: Absence of the wild-type allele (192 base pairs) of a polymorphism in the promoter region of the IGF-I gene but not a polymorphism in the insulin gene variable number of tandem repeat locus is associated with accelerated weight gain in infancy. Pediatrics 2006;118: 2374-2379.

2 Bazaes RA, Petry CJ, Ong KK, Avila A, Dunger DB, Mericq MV: Insulin gene VNTR genotype is associated with insulin sensitiv- 
ity and secretion in infancy. Clin Endocrinol (Oxf) 2003;59:599-603.

-3 Dunger DB, Ong KK, Huxtable SJ, Sherriff A, Woods KA, Ahmed ML, Golding J, Pembrey ME, Ring S, Bennett ST, Todd JA: Association of the INS VNTR with size at birth. ALSPAC Study Team. Avon Longitudinal Study of Pregnancy and Childhood. Nat Genet 1998;19:98-100.

4 Mook-Kanamori DO, Miranda Geelhoed JJ, Steegers EA, Witteman JC, Hofman A, Moll HA, van Duijn CM, Hokken-Koelega AC, Jaddoe VW: Insulin gene variable number of tandem repeats is not associated with weight from fetal life until infancy: the Generation R Study. Eur J Endocrinol 2007;157:741748.

5 Ong KK, Petry CJ, Barratt BJ, Ring S, Cordell HJ, Wingate DL, Pembrey ME, Todd JA, Dunger DB; Avon Longitudinal Study of Pregnancy and Childhood Study T: Maternal-fetal interactions and birth order influence insulin variable number of tandem repeats allele class associations with head size at birth and childhood weight gain. Diabetes 2004;53:1128-1133.

-6 Bennett AJ, Sovio U, Ruokonen A, Martikainen H, Pouta A, Taponen S, Hartikainen AL, King VJ, Elliott P, Jarvelin MR, McCarthy MI: Variation at the insulin gene VNTR (variable number tandem repeat) polymorphism and early growth: studies in a large Finnish birth cohort. Diabetes 2004;53: 2126-2131.

7 Missmer SA, Haiman CA, Hunter DJ, Willett WC, Colditz GA, Speizer FE, Pollak MN, Hankinson SE: A sequence repeat in the insulin-like growth factor-1 gene and risk of breast cancer. Int J Cancer 2002;100:332336.

8 Rosen CJ, Kurland ES, Vereault D, Adler RA, Rackoff PJ, Craig WY, Witte S, Rogers J, Bilezikian JP: Association between serum insulin growth factor-I (IGF-I) and a simple sequence repeat in IGF-I gene: implications for genetic studies of bone mineral density. J Clin Endocrinol Metab 1998;83:22862290.

9 Vaessen N, Heutink P, Janssen JA, Witteman JC, Testers L, Hofman A, Lamberts SW, Oostra BA, Pols HA, van Duijn CM: A polymorphism in the gene for IGF-I: functional properties and risk for type 2 diabetes and myocardial infarction. Diabetes 2001;50: 637-642.

10 Vaessen N, Janssen JA, Heutink P, Hofman A, Lamberts SW, Oostra BA, Pols HA, van Duijn CM: Association between genetic variation in the gene for insulin-like growth factor-I and low birth weight. Lancet 2002; 359:1036-1037.

11 Voorhoeve PG, van Rossum EF, Te Velde SJ, Koper JW, Kemper HC, Lamberts SW, de Waal HA: Association between an IGF-I gene polymorphism and body fatness: differences between generations. Eur J Endocrinol 2006;154:379-388.
12 Frayling TM, Hattersley AT, McCarthy A, Holly J, Mitchell SM, Gloyn AL, Owen K, Davies D, Smith GD, Ben-Shlomo Y: A putative functional polymorphism in the IGF-I gene: association studies with type 2 diabetes, adult height, glucose tolerance, and fetal growth in UK populations. Diabetes 2002; 51:2313-2316.

$\checkmark 13$ Geelhoed JJ, Mook-Kanamori DO, Witteman JC, Hofman A, van Duijn CM, Moll HA, Steegers EA, Hokken-Koelega AC, Jaddoe VW: Variation in the IGF1 gene and growth in foetal life and infancy. The Generation $\mathrm{R}$ Study. Clin Endocrinol (Oxf) 2008;68:382389.

14 Heude B, Petry CJ; Avon Longitudinal Study of Parents Children (ALSPAC) study team, Pembrey M, Dunger DB, Ong KK: The insulin gene variable number of tandem repeat: associations and interactions with childhood body fat mass and insulin secretion in normal children. J Clin Endocrinol Metab 2006;91:2770-2775.

15 Thorsby PM, Berg JP, Birkeland KI: Insulin gene variable number of tandem repeats is associated with increased fat mass during adolescence in non-obese girls. Scand J Clin Lab Invest 2005;65:163-168.

16 Nader PR, O'Brien M, Houts R, Bradley R, Belsky J, Crosnoe R, Friedman S, Mei Z, Susman EJ; National Institute of Child Health and Human Development Early Child Care Research Network: Identifying risk for obesity in early childhood. Pediatrics 2006;118: e594-e601.

17 Ong KK, Ahmed ML, Emmett PM, Preece MA, Dunger DB: Association between postnatal catch-up growth and obesity in childhood: prospective cohort study. BMJ 2000; 320:967-971.

18 Stettler N, Zemel BS, Kumanyika S, Stallings VA: Infant weight gain and childhood overweight status in a multicenter, cohort study. Pediatrics 2002;109:194-199.

19 Jaddoe VW, Bakker R, van Duijn CM, van der Heijden AJ, Lindemans J, Mackenbach JP, Moll HA, Steegers EA, Tiemeier H, Uitterlinden AG, Verhulst FC, Hofman A: The Generation R Study Biobank: a resource for epidemiological studies in children and their parents. Eur J Epidemiol 2007;22:917-923.

20 Jaddoe VW, Mackenbach JP, Moll HA, Steegers EA, Tiemeier H, Verhulst FC, Witteman JC, Hofman A: The Generation R Study: design and cohort profile. Eur J Epidemiol 2006;21:475-484.

21 Stead JD, Jeffreys AJ: Structural analysis of insulin minisatellite alleles reveals unusually large differences in diversity between Africans and non-Africans. Am J Hum Genet 2002;71:1273-1284.

22 Le Stunff C, Fallin D, Bougneres P: Paternal transmission of the very common class I INS VNTR alleles predisposes to childhood obesity. Nat Genet 2001;29:96-99.

23 Weber JL, May PE: Abundant class of human DNA polymorphisms which can be typed using the polymerase chain reaction. Am J Hum Genet 1989;44:388-396.

24 Allen NE, Davey GK, Key TJ, Zhang S, Narod SA: Serum insulin-like growth factor I (IGF-I) concentration in men is not associated with the cytosine-adenosine repeat polymorphism of the IGF-I gene. Cancer Epidemiol Biomarkers Prev 2002;11:319-320.

25 Mitchell SM, Hattersley AT, Knight B, Turner T, Metcalf BS, Voss LD, Davies D, McCarthy A, Wilkin TJ, Smith GD, Ben-Shlomo Y, Frayling TM: Lack of support for a role of the insulin gene variable number of tandem repeats minisatellite (INS-VNTR) locus in fetal growth or type 2 diabetes-related intermediate traits in United Kingdom populations. J Clin Endocrinol Metab 2004;89: 310-317.

26 Shields BM, Knight BA, Powell RJ, Hattersley AT, Wright DE: Assessing newborn body composition using principal components analysis: differences in the determinants of fat and skeletal size. BMC Pediatr 2006;6: 24.

27 Nevill AM, Stewart AD, Olds T, Holder R: Relationship between adiposity and body size reveals limitations of BMI. Am J Phys Anthropol 2006;129:151-156.

28 Sardinha LB, Going SB, Teixeira PJ, Lohman TG: Receiver operating characteristic analysis of body mass index, triceps skinfold thickness, and arm girth for obesity screening in children and adolescents. Am J Clin Nutr 1999;70:1090-1095.

29 Ay L, Hokken-Koelega AC, Mook-Kanamori DO, Hofman A, Moll HA, Mackenbach JP, Witteman JC, Steegers EA, Jaddoe VW: Tracking and determinants of subcutaneous fat mass in early childhood: the Generation $\mathrm{R}$ Study. Int J Obes (Lond) 2008;32:1050-1059.

30 Bland JM, Altman DG: Statistical methods for assessing agreement between two methods of clinical measurement. Lancet 1986;1: 307-310.

31 Bleumink GS, Rietveld I, Janssen JA, van Rossum EF, Deckers JW, Hofman A, Witteman JC, van Duijn CM, Stricker BH: Insulinlike growth factor-I gene polymorphism and risk of heart failure (the Rotterdam Study). Am J Cardiol 2004;94:384-386.

32 te Velde SJ, van Rossum EF, Voorhoeve PG, Twisk JW, Delemarre van de Waal HA, Stehouwer CD, van Mechelen W, Lamberts SW, Kemper HC: An IGF-I promoter polymorphism modifies the relationships between birth weight and risk factors for cardiovascular disease and diabetes at age 36. BMC Endocr Disord 2005;5:5

33 Wells JC, Victora CG: Indices of whole-body and central adiposity for evaluating the metabolic load of obesity. Int J Obes (Lond) 2005; 29:483-489.

34 Wells JC, Fewtrell MS: Measuring body composition. Arch Dis Child 2006;91:612-617.

35 Wells JC, Fewtrell MS: Is body composition important for paediatricians? Arch Dis Child 2008;93:168-172. 